\title{
Development of curriculum design evaluation instruments in strengthening Al-Irsyad ideology in Indonesia
}

\author{
Joko Subando, Badrun Kartowagiran, Sudji Munadi \\ Educational Research and Evaluation, Graduate School, Yogyakarta State University, Indonesia
}

\begin{tabular}{l} 
Article Info \\
\hline Article history: \\
Received Feb 18, 2021 \\
Revised Aug 25, 2021 \\
Accepted Sep 13, 2021 \\
\hline
\end{tabular}

\section{Keywords:}

Al-Irsyad ideology

Curriculum design

Evaluation instrument

\begin{abstract}
The purpose of this research was to develop a curriculum design evaluation instrument in strengthening Al-Irsyad ideology. The research activity began with a literature review on the curriculum then continues with the development of the instrument. The results of the development of the instrument items were validated by 11 experts and tested on a limited scale by involving 17 teachers from Al-Irsyad Junior High School, Surakarta, Cirebon, and Purwokerto, Indonesia. The next activity was an expanded trial involving 53 teachers from Al-Irsyad schools in West Java, Central Java, and East Java, the territory of the Republic of Indonesia. Data from expert reviews were analyzed by using Aiken's formula. Limited trial data were analyzed with the EFA model using the help of the SPSS program, and data from the extended trial results were analyzed by CFA using the help of the Smart PLS version 2.0 program. The results indicated that the instrument has a good validity guarantee because the loading factor value ranges from 0.5571-0.9463 (>0.5), and the AVE value ranges from 0.5901-0.8051 (>0.5), and has guaranteed reliability because of the CR value ranges from 0.8394 0.9397 (>0.7) and Cronbach alpha ranges from 0.7692-0.9286 (>0.7). The instrument feasible to be used as a measurement tool in evaluating the AlIrsyad curriculum design in Indonesia.
\end{abstract}

This is an open access article under the CC BY-SA license.

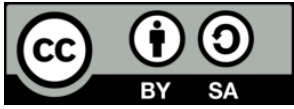

\section{Corresponding Author:}

Joko Subando

Educational Research dan Evaluation, Graduate School

Yogyakarta State University

Caturtunggal, Sleman Regency, Special Region of Yogyakarta, Indonesia

Email: joko.subando2015@student.uny.ac.id

\section{INTRODUCTION}

Ideology has a strong relationship with education [1]. As evidence, firstly, the choice of learning strategies between authoritarianism versus permissiveness, gender separation versus co-education is an ideological choice that teachers choose for students based on certain ideological choices. Secondly, education is an act of conscious purpose, meaning that educational activity is an action guided by specific ideological values so that education functions to comply with ideological decisions [2].

In Indonesia, the discourse on ideological relations, especially religious ideology and education, strengthened in 2000. The strengthening of the relationship between ideology and education is because the Indonesian government provides opportunities for various ideologies to grow and develop for showing their identity, including trans-national ideologies [3]. As a result, various religious groups with their communal ideological identities, both theological and social have emerged, such as Al-Irsyad, Muhammadiyah, Nahdlatul Ulama (NU), Salafi, and political identities such as Partai Keadilan Sejahtera (PKS). The existence 
of religious groups has implications for the emergence of contestations between ideologies and various efforts to strengthen communal ideology to maintain the sustainability and existence of the movement [4].

Ideology requires a system structure. According to Althusser, strengthening ideology requires an ideological apparatus as cadres who maintain the sustainability of ideology [5]. To fulfill the demands and support of these ideologies, various religious groups have established formal educational institutions, such as the Al-Irsyad, Muhammadiyah, Ma'arif schools, Salafi madrasa, and integrated Islamic network schools founded by PKS activists. Tan introduces the results of research which concludes that at the beginning of the reform era, Islamic education in Indonesia was considered as a ground for ideological indoctrination [6]. Educational institutions have a system structure supporting ideological development through curriculum and movement cadres.

Education in the structure of society is a strategic place as a means of disseminating ideology and producing ideological apparatus. The ideological apparatus in the educational environment moves with a certain modus operandi through various aspects of education such as curriculum, extracurricular activities, religious activities in schools, textbooks, coaching educational subjects, and various existing regulations. The curriculum is an important element in the dissemination of ideology. Ideological messages formulated and packaged into subjects as a written curriculum are conveyed by the organization to strengthen the communal ideology. Likewise, learning activities conveyed by the teacher as an ideological apparatus will create an unwritten curriculum (hidden curriculum) that binds all ideological supporters and becomes a justification for the social interests in their environment.

The importance of curriculum in disseminating ideology implies that the evaluation of curriculum design is also an important activity. The evaluation process includes activities to assess whether educational goals reinforce ideological values, whether curriculum content contains ideological values, whether learning activities are following the objectives and content prepared, and finally whether learning outcomes assessment activities assess the achievement of educational goals [7]. So, evaluation of the curriculum design is to ascertain whether the curriculum goals have been achieved or not, whether ideological values have been internalized in students or not.

Based on literature searching, research has been found related to curriculum evaluation in various schools with certain mass organization backgrounds. For example, Huda's research on the evaluation of the Al-Islam Kemuhamammadiyahan curriculum and integrated holistic-based Arabic language at Muntilan Muhammadiyah High School 1 [8]. The results indicate that the learning process of these subjects is following the direction of the elementary school council by paying attention to a holistic integrative curriculum-based, combining knowledge and charity, and involving school culture with Islamic values. Shodiq researches the evaluation of the NU's curriculum at Ma'arif Kudus High School. The results show that NU's learning succeeded in transmitting and disseminating the NU version of the Ahlussunnah Al-Jama'ah, as well as strengthening the NU's character and fanaticism of its students [9]. However, an evaluation of the curriculum design in strengthening Al-Irsyad's ideology has not been studied yet.

Al-Irsyad and Muhammadiyah understand Islam based on the Quran and Sunnah, they are not tied to madzhab (schools of thought). While, NU understands Islam by following the four Imam madzhab. AlIrsyad and Muhammadiyah are tajdid movements, that is the purification of shirk in aqidah (doctrine), purification of heresy in worship, straightening activities from deviant things in terms of morals, modernization in worldly matters. Hence, NU continues to maintain classical traditions such as tahlilan (declaration of Allah oneness), maulid (birth commemoration of Prophet Muhammad), and ziyarotul qubuur (visiting the graves). Muhammadiyah positions itself as moderate Islam, non-radical and not liberal, and adheres to the principles of tawasut (middle), tawazun (balanced), and ta'adul (fair). NU takes position as the Islam Nusantara that protects the Republic of Indonesia. Meanwhile, Al-Irsyad positions is a movement that adheres to Islam and not labeled [10]-[12].

Al-Irsyad is a religious organization founded two years after Muhammadiyah precisely on September 6th, 1914. Currently, this organization still exists with its distinctive ideological character. However, existing researches have not yet penetrated the area of curriculum evaluation in strengthening ideology. Existing researches are limited to historical research such as the diaspora of the Hadrami struggling to establish Al-Irsyad [13], regarding the thoughts of the reformer founder of Al-Irsyad, namely Shaykh Ahmad Surkati [14], and research on internal conflicts in Al-Irsyad organization [15]. Famela briefly examines Al-Irsyad curriculum design, while Maulana evaluates the affective domain of Al-Irsyad's education [16]. However, those studies do not develop the curriculum evaluation instruments from the aspect of strengthening their ideology. Based on the explanation, this study aimed to develop a curriculum design evaluation instrument in strengthening Al-Irsyad ideology.

The Central Executive (Pimpinan Pusat/PP) of Al-Irsyad has schools ranging from early childhood education (Pendidikan Anak Usia Dini/PAUD) to university, but the development of this instrument is carried out at the secondary education level with the following considerations: i) Junior high school students 
are considered to have understood ideology rationally, not doctrinal; ii) Junior high school level is the school most owned by PP Al-Irsyad so that trials can be carried out widely; iii) Successfully developed instrument at the junior high school level can be used at a higher level.

The importance of this research is that the junior high school education level is an advanced level of primary school which is part of the nine-year compulsory education program. Al-Irsyad as an education provider needs to prepare instruments to evaluate whether the applied curriculum is following the objectives of Al-Irsyad's establishment. This research is also important for other religious organizations such as NU and Muhammadiyah, that is as a basis for developing curriculum design evaluation instruments in strengthening the ideology of Muhammadiyah and NU or other religious organizations.

\section{RESEARCH METHOD}

This study was research and development by adapting the ADDIE development model [17]. The research steps are shown in Figure 1. First, the analysis: at the stage of reviewing curriculum books, the expected results were operational concepts and indicators of the curriculum evaluation construct. Secondly, the design: at this stage, the preparation of curriculum evaluation instrument items were carried out in strengthening ideology, the expected results were a prototype of a curriculum evaluation instrument. Thirdly, the development; at this stage, a peer review and the validity of the contents of the instrument were carried out. The peer review was conducted on September 13th, 2019, involving 13 doctoral students from Yogyakarta State University with various educational backgrounds, they are: four measurement experts, five evaluation experts, one special education expert, and two Islamic education experts. Instrument validation was carried out by involving 11 experts with various educational backgrounds, they are: two education measurement and evaluation experts, one curriculum evaluation expert, one educational evaluation expert, four experts of Al-Irsyad curriculum, two Islamic education experts, and one linguist. The minimum number of experts in Aiken's validity is two people, but in this study, 11 experts are involved with the following considerations: Measurement expert is needed to assess the possibility of bias in the instrument, education expert is needed to assess curriculum component, Al-Irsyad curriculum expert is needed to assess whether the developed instrument can measure curriculum design in Al-Irsyad ideological strengthening process and linguist is involved to assess whether the terms used in the instrument match the prospective respondents who will use the instrument. The expected outcome at this stage was a well-validated evaluation instrument.

Fourthly, the implementation: at this stage, a limited trial was carried out and it was expanded. The limited trial was conducted at Al-Irsyad Junior High School, Purwokerto, Cirebon, and Surakarta, involving 15 teachers. The trial activity was carried out in October 2019. The expanded trial was carried out from November 2019 to February 2020 involving 55 teachers in various schools in Java, namely Junior High School of Al-Irsyad Purwokerto, Karawang, Cirebon, Pemalang, Surakarta, Bondowoso, and Banyuwangi. Fifthly, the evaluation: the evaluation activity was conducted together with the implementation; invalid items were dropped from the instrument, so the remaining items were valid and reliable instrument items.

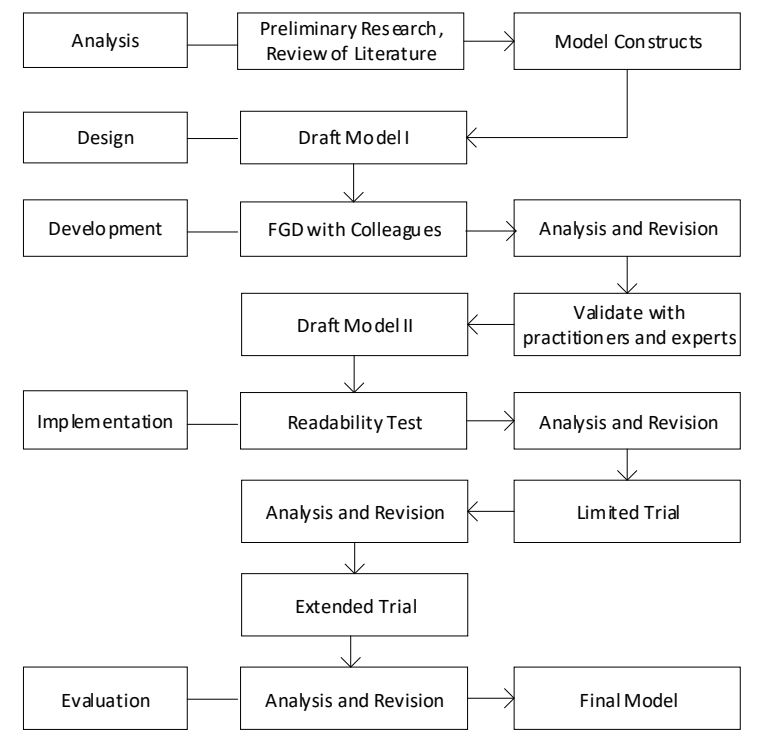

Figure 1. Development procedure of curriculum design evaluation instruments 
The curriculum component included objectives, content, learning, and evaluation activities. The objective indicators were scope, consistency; curriculum content indicators included content support in strengthening ideology (self-sufficiency), learnability, feasibility. Learning activities include diversity (variety), linkage (relevance); assessment indicators included the scope of the evaluation (scope), linkage with objectives (relevance). The curriculum design evaluation instrument had 37 items consisting of 12 objective items, 14 curriculum content items, five learning activity items, and five assessment items. The instrument applied a Likert scale with the following answers: strongly agree (4), agree (3), disagree (2), and strongly disagree (1).

The assessment scores from the expert were analyzed with Aiken's formula. The criteria for instrument evidence are considered to be valid if the formula Aiken's value is $>0.897$ [18]. Data from limited trial results were analyzed by using the Exploratory Factor Analysis (EFA) technique and the help of the SPSS version 20 program. For the evaluation criteria, if the KMO value is $>0.05$ and the BTS value is $<0.05$, the data is suitable for further analysis. If the AIC value is $>0.05$ and LF>0.05, the instrument is considered to be valid. If the value of Cronbach alpha and construct reliability is $>0.07$ then the instrument is reliable [19]. The data from the expanded trial were analyzed using confirmatory factor analysis (CFA) and the Smart PLS 2.0 program. The instrument is valid if the standardized loading factor (SLF) value is $>0.5$ [20]-[22].

\section{RESULTS AND DISCUSSION}

\subsection{Results}

\subsubsection{Content validity}

The evaluation instrument has been validated by 11 experts. Linguist provides input that some terms such as concrete are replaced with real terms, abstracts are replaced with virtual terms, because these terms cannot be understood by students. The mean score of the assessment of the component accuracy score with the indicator is 0.937 and the average score of the accuracy of the indicator with the statement is 0.903 . The detail is shown in Table 1. Based on Aiken, because V Aiken's count $>\mathrm{V}$ Aiken's table $(\mathrm{V}=0.781)$, the instrument item is declared valid [18].

Table 1 . Aiken's validity value

\begin{tabular}{cccc}
\hline \multirow{2}{*}{ Dimension } & \multirow{2}{*}{ Aspect } & \multicolumn{2}{c}{ Average value of Aiken's validity } \\
& & Component with indicator & Indicator with statement \\
\hline Design & Objective & 0.92 & 0.93 \\
& Content & 0.91 & 0.89 \\
& Activity & 0.94 & 0.90 \\
& Assessment & 0.94 & 0.87 \\
\hline
\end{tabular}

\subsubsection{Construct validity}

Valid items were then tested in small groups to see the instrument readability. The instrument readability test was conducted at Al-Iryad Junior High School Surakarta in September 2019 involving seven teachers. The legibility test results conclude the respondents easily understood the evaluation instrument. Instrument items that passed the legibility test were then tested on a limited basis at Junior High School of Al-Irsyad Purwokerto, Surakarta, and Cirebon. The limited trial involved 17 teachers and was conducted in October-November 2019.

The test results for the objective component indicate that the data have fulfilled the sufficiency requirements because the KMO-MSA value is $0.618(>0.05)$, the Bartlet's test of Sphericity (BTS) index is $0.000(<0.05)$, so the data can be analyzed further. Anti-Image correlation values are TUJ1 (0.624), TUJ2 (0.697), TUJ3 (0.628), TUJ4 (0.554), TUJ5 (0.658), TUJ7 (0.822), TUJ8 (0.788), TUJ9 (0.769), TUJ10 (0.756), TUJ11 (0.663), TUJ12 (0.673), TUJ13 (0.735), while the Loading Factor values are TUJ1 (0.657), TUJ2 (0.589), TUJ3 (0.876), TUJ4 (0.887), TUJ5 (0.715), TUJ7 (0.836), TUJ80. 507), TUJ9 (0.667), TUJ10 (0.628), TUJ11 (0.881), TUJ12 (0.873), TUJ13 (0.800), because AIC $>>0.5$ and FL $>0.5$, then the items are valid [23]. Analysis of the estimation of the instrument reliability coefficient with the Cronbach Alpha formula obtains a value of $0.832(>0.7)$, so the instrument is reliable [24].

The curriculum content component has a KMO-MSA value of $0.650(>0.05)$, the Bartlet's test of Sphericity (BTS) index of $0.000(<0.05)$, so it is considered to meet the sufficiency requirements and the data can be analyzed further. KON1 (0.637), KON2 (0.886), KON3 (0.542), KON4 (0.859), KON5 (0.542), KON6 (-.829), KON9 (0.603), KON10 (0.608), KON11 (0.614), KON12 (0.500) ), KON13 (0.513), KON14 (0.757), and KON1 (0.783), KON2 (0.813), KON3 (0.860), KON4 (0.696), KON5 (0.914), KON6 (0.636), KON9 (0.818), KON10 ( 0.715), KON11 (0.739), KON12 (0.857), KON13 (0.815), KON14 (0.889), because 
AIC $>>0.5$ and FL $>0.5$ then the item details are valid [25]. Analysis of the estimation of the instrument reliability coefficient with the Cronbach Alpha formula obtains a value of $0.852(>0.7)$, so the instrument is reliable.

The learning activity component has a KMO-MSA value of 0.551 (>0.05), Bartlet's Test of Sphericity (BTS) index of $0.000(<0.05)$, so it is considered to meet the adequacy requirements and the data can be analyzed further. The AIC value for each item is AKT1 (0.544), AKT2 (0.527), AKT3 (0.574), AKT4 (0.532), AKT5 (0.602) and the FL value for each item AKT1 (0.831), AKT2 (0.525), AKT3 (0.734), AKT4 (0.801), AKT5 (0.873), because AIC $>0.5$ and FL>0.5, then the item requirement is valid [23], [25]. Analysis of the estimation of the instrument reliability coefficient with the Cronbach Alpha formula obtains a value of $0.713(>0.7)$, so the instrument is reliable.

The evaluation component has a KMO-MSA value of 0.526 (>0.05), Bartlet's Test of Sphericity (BTS) index is $0.000(<0.05)$, so it is considered to meet the requirements for sufficiency and the data can be analyzed further. AIC values are NIL1 (0.748), NIL3 (0.870), NIL4 (0.866), NIL5 (0.705) and FL values are NIL1 (0.862), NIL3 (0.745), NIL4 (0.753), NIL5 (0.903), because AIC $>0.5$ and FL $>0.5$, then the items are valid [23], [25]. Analysis of the estimation of the instrument reliability coefficient with the Cronbach Alpha formula obtains a value of $0.821(>0.7)$, so the instrument is reliable. So, the number of valid instrument items up to the limited trial stage is 33 items consisting of curriculum objectives (12 items), curriculum content (12 items), learning activity (5 items), and evaluation (4 items) as shown in Table 2.

Table 2. Number of instrument items

\begin{tabular}{ccccc}
\hline \multirow{2}{*}{ No } & \multirow{2}{*}{ Component } & Early development & \multicolumn{2}{c}{ Limited trial } \\
& & Valid & non-valid & valid \\
\hline 1 & Curriculum objectives & 13 & 2 & 12 \\
2 & Curriculum content & 14 & 0 & 12 \\
3 & Learning activity & 5 & 1 & 5 \\
4 & Evaluation & 5 & 4 & 4 \\
& Total & 37 & & 33 \\
\hline
\end{tabular}

The results of the expanded trial were carried out from November 2019 to February 2020, involving teachers from Junior High School of Al-Irsyad Karawang, Al-Irsyad Bandung, Al-Irsyad Tawangmangu Karanganyar, Al-Irsyad Bondowoso, Al-Irsyad Tulungagung, and Al-Irsyad Banyuwangai. It is obtained the following results; the loading factor value for the objective construct of FL values are BTR01 (0.634), BTR03 (0.567), BTR04 (0.739), BTR05 (0.836), BTR06 (0.669), BTR07 (0.634) as can be seen in Figure 2. The T value is BTR01 (2.326), BTR03 (2.119), BTR04 (2.871), BTR05 (4.144), BTR06 (2.958), BTR07 (4.896) as displayed in Figure 3; because the lowest FL is $0.5672(>0.5)$ and the lowest t-value is 2.119 $(>1.96, \alpha=5 \%)$, then the instrument items for the objective construct have a guarantee of convergent validity [24], [26].

The content construct has the following FL values is shown in Figure 2 as: BTR08 (0.841), BTR09 (0.788), BTR10 (0.776), BTR11 (0.774), BTR12 (0.799), BTR13 (0.874), BTR16 (0.587), BTR17 (0.641), BTR18 (0.635), BTR20 (0.885), BTR21 (0.793) and the t value is BTR08 (13.069), BTR09 (7.193), BTR10 (9.473), BTR11 (9.121), BTR12 (8.930), BTR13 (13.923), BTR16 (3.135), BTR17 (5.143), BTR18 (4.196), BTR20 (16.197), BTR21 (6.729). Because the lowest FL value is $0.587(>0.5)$ and the lowest t-value is 3.135 $(>1.96, \alpha=5 \%)$ as in Figure 3, the instrument items for the content construct have a guarantee of convergent validity [27]. 


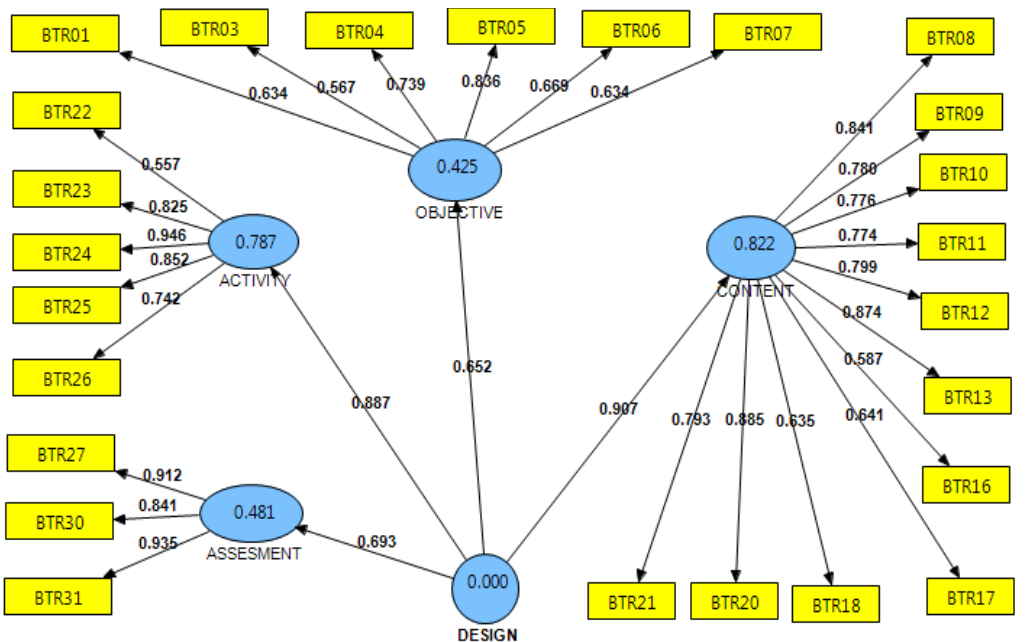

Figure 2. Loading factor of curriculum design constructs

Based on Figure 2, the activity construct has the following FL values: BTR22 (0.557), BTR23 (0.825), BTR24 (0.946), BTR25 (0.852), BTR26 (0.742) and the t value is BTR22 (2.496), BTR23 (9.118), BTR24 (36.861), BTR25 (21.937), BTR26 (6.468). Because the lowest FL value is 0.557 (>0.5), and the lowest $\mathrm{T}$ value is $2.496(>1.96, \alpha=5 \%)$ as shown in Figure 3, the instrument items for the activity construct have a guarantee of convergent validity [27].

The assessment construct has the following FL values: BTR27 (0.912), BTR30 (0.841), BTR31 (0.935) and the t-values are BTR27 (3.815), BTR30 (3.536), BTR31 (3.777). Because the lowest FL value is $0.841(>0.5)$ and the lowest $t$ value is $3.536(>1.96, \alpha=5 \%)$, the instrument items for the assessment construct have a guarantee of convergent validity [27].

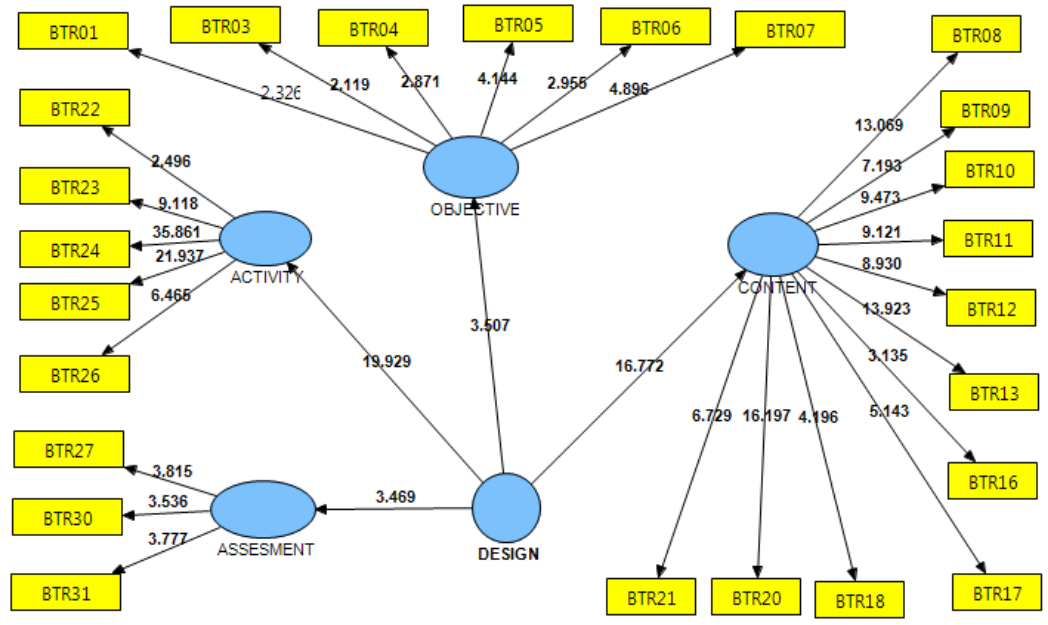

Figure 3. The t-value of the curriculum design construct

\subsubsection{Discriminant Validity}

The assurance of discriminant validity is shown in Table 3. The value of the square root of the AVE activity (0.795) is higher than the activity-content correlation value (0.7791), the activity-assessment correlation value (0.586), and the activity-objective correlation value (0.396). The value of the square root of AVE content (0.768) is higher than the correlation value of content with ratings $(0.385)$, and the correlation of content with objectives (0.404). The value of the square root of the AVE for assessments (0.897) is higher than the correlation value for the assessment and objectives. This indicates that the instrument has discriminant validity [28], [29]. 
Table 3. Discriminant validity values

\begin{tabular}{|c|c|c|c|c|}
\hline Component & Activity & Content & Assessment & Objective \\
\hline Activity & $\sqrt{\mathrm{AVE}_{\text {activity }}}=0.795$ & $\begin{array}{l}\text { Content-activity } \\
\text { correlation }=0.771\end{array}$ & $\begin{array}{c}\text { Assessment correlation } \\
\text { with activity }=0.586\end{array}$ & $\begin{array}{c}\text { Correlation of objectives } \\
\text { with activities }=0.396\end{array}$ \\
\hline Content & $\begin{array}{l}\text { Content-activity } \\
\text { correlation }=0.771\end{array}$ & $\sqrt{\mathrm{AVE}_{\text {content }}}=0.768$ & $\begin{array}{l}\text { Assessment correlation } \\
\text { with content }=0.385\end{array}$ & $\begin{array}{c}\text { Correlation of goals with } \\
\text { content }=0.404\end{array}$ \\
\hline Assessment & $\begin{array}{l}\text { Assessment correlation } \\
\text { with activity }=0.586\end{array}$ & $\begin{array}{l}\text { Assessment correlation } \\
\text { with content }=0.385\end{array}$ & $\sqrt{\mathrm{AVE}_{\text {assessment }}}=0.897$ & $\begin{array}{l}\text { Correlation of objectives } \\
\text { with assessments }=0.631\end{array}$ \\
\hline Objective & $\begin{array}{c}\text { Correlation of objectives } \\
\text { with activities }=0.396\end{array}$ & $\begin{array}{c}\text { Correlation of goals with } \\
\text { content }=0.404\end{array}$ & $\begin{array}{l}\text { Correlation of objectives } \\
\text { with assessments }=0.631\end{array}$ & $\sqrt{\mathrm{AVE}_{\text {objectives }}}=0.685$ \\
\hline
\end{tabular}

\subsubsection{Reliability}

The composite reliability (CR) value of the activity construct is 0.8933 , the content is 0.9397 , the assessment is 0.9252 , and the objective is 0.8394 . The Cronbach alpha value for the activity construct is 0.848 , the content is 0.9286 , the assessment is 0.8786 and the objective is 0.7692 as shown in Table 4 . Because the majority of CR value is $>0.7$ and Cronbach's alpha is $>0.7$, it is concluded that the instrument has an internal guarantee of reliability consistency [26].

The results of the expanded trial obtain 31 valid instrument items consisting of objectives, content, activities, and assessments. After securing the item's validity and reliability guarantees, the instrument can be used to evaluate the curriculum with the following criteria as shown in Table 5.

Table 4. Value of consistency reliability

\begin{tabular}{ccc}
\hline \multirow{2}{*}{ Component } & \multicolumn{2}{c}{ Internal consistency reliability } \\
& Composite Reliability & Cronbach's Alpha \\
\hline Activity & 0.8933 & 0.848 \\
Content & 0.9397 & 0.9286 \\
Assessment & 0.9252 & 0.8786 \\
Objective & 0.8394 & 0.7692 \\
\hline
\end{tabular}

Table 5. Criteria of curriculum design evaluation [30]

\begin{tabular}{ccc}
\hline No & Score & Category \\
\hline 1 & $1.00-1.59$ & Very bad \\
2 & $1.60-2.19$ & Bad \\
3 & $2.20-2.79$ & Sufficient \\
4 & $2.80-3.39$ & Good \\
5 & $3.40-4.00$ & Excellent \\
\hline
\end{tabular}

\subsection{Analysis}

A curriculum is a learning design to achieve educational goals and a curriculum must answer four basic questions, including: i) what is the purpose of the school, ii) what learning materials must be prepared to achieve school goals, iii) how to present effective learning materials, iv) how to assess the effectiveness of learning. Based on the previous items, the curriculum component must include four things, namely: i) objectives, ii) subject matter, iii) learning process, and iv) evaluation [31].

The curriculum evaluation instrument in strengthening Al-Irsyad ideology consists of four constructs and 31 items, namely objectives/goals, content, learning activities, and assessment. The objective constructs in strengthening Al-Irsyad's ideology measures the clarity of competency standards (SK) and basic competence (KD), SK/KD support for the achievement of Al-Irsyad objectives, the suitability of SK/KD with students' abilities, and the content of Al-Irsyad ideology in SK/KD, such as understanding and practicing the content of the Quran, staying away from fanaticism and blind taqlid, monetizing Allah, staying away from shirk, abandoning heretical practices, telling the truth, treating people fairly, utilizing technology, helping each other and establishing a friendship.

The idea is consistent with Brady and Kennedy statement that the criteria for setting curriculum goals include: i) relevance: the correlation between goals and situations and social contexts, ii) validity: reflecting the value to be presented (ideology), iii) feasibility: goals that can be achieved with students' abilities and availability of learning resources existing, iv) compatible: consistency between instructional goals and institutional goals [32]. The results of the study also reinforce Sanjaya's statement that the criteria for setting curriculum goals are: i) conformity between subject objectives and institutional goals, ii) ease of understanding goals, iii) conformity of the formulation of objectives with the level of student development [33].

Int J Eval \& Res Educ, Vol. 10, No. 4, December 2021: 1426 - 1435 
In the subject matter, the curriculum construct measures the support of learning content in realizing religious principles in Al-Irsyad, the content ability to make students function in society when they are adults, the content suitability with students' development, infrastructure, and time availability, linkages between subjects, and organizing content in learning such as content accuracy based on material complexity, a content sequence from concrete to abstract, content suitability with the context of learning time.

The results of this study are following the criteria for determining content according to Ornstein and Hunkins criteria, namely: i) self-sufficiency: the material studied can make students independent in developing intellectual, emotional and spiritual potential, as well as help students become the whole individual, ii) Significant in shaping student attitudes is to facilitate the students to live normally in society, iii) utility: materials to equip students for activities in society iv) learnability: curriculum content following the environment and level of student development, v) feasibility, adequate facilities and infrastructure to convey material [34].

The criteria for establishing a curriculum organization are following Ansyar's opinion, namely: integration, order, and sustainability [35]. Integration is the relationship among subjects, and the relationship between learning experiences in the classroom and outside the classroom [34], [35]. The order is putting content, learning activities in an arrangement that is getting wider and deeper [35]. The content sequence model is from simple to complex, from familiar to unknown, from concrete to abstract. Continuity is the development of understanding getting deeper and wider in line with the progress of student learning.

In the learning process, the construct of learning activities measures learning support with the aim of Al-Irsyad. The clarity of strategies in learning measures the ability of teachers to teach reasoning skills assesses various religious activities in schools in supporting the formation of student habits following AlIrsyad ideology and measures the application of skills and knowledge in learning. This is according to Sanjaya opinion that the criteria for determining learning activities are: i) supporting educational goals, ii) encouraging students' interest in learning and teachers' creativity, iii) easy to understand, iv) based on the level of students' development and time allocation [33].

The results of this study are following the opinion of Ornstein and Hunkins that the determining criteria for learning activities are: i) clarity of the steps to apply knowledge and skills outside school situations; ii) availability of time, facilities, adequate personnel; iii) maximizing students learning content; iv) developing thinking skills and reasoning power; v) stimulating students to understand themselves as individuals and members of society; vi) fostering students to open up new experiences and to accept diversity; vii) facilitating learning and encouraging students to continue learning, viii) serving students' needs; ix) expanding students' interest, x) fostering cognitive, affective, psychomotor, social and spiritual development aspects [34]. The results also reinforce the opinion from Taba that to make an effective learning activity based on learning objectives, learning activities must provide various kinds of learning models [36].

In evaluation, the evaluation construct measures on the assessment to have clear criteria following the learning objectives, to cover various aspects of learning, to measure the process, not just results, as well as a follow-up program of the assessment. According to Sanjaya's opinion that the criteria for evaluating learning are relevant to the curriculum objectives, easy to read and understand and cover all aspects of learning (cognitive, affective, and psychomotor) [33]. Ornstein and Hunkins also argue learning evaluation criteria include developing students' potential, referring to clear criteria, covering cognitive, affective, and psychomotor aspects, facilitating students' learning, measuring instructional effects [34]. The results of the study are also following Harris, Hobart, and Lundberg research that the evaluation criteria are: i) Validity: includes competence in knowledge and skills; ii) Reliability: monitored by competent evaluators; iii) Flexibility: includes competencies in the classroom and outside the classroom; iv) Fairness: the evaluation process and methods are fair for all groups [37] and consistent to the criteria according to Brady and Kennedy are: i) Varies: allows students to show what they have mastered; ii) Diagnostic: evaluation strategy can show not only the results but the processes that lead students to achieve the results; iii) Overall mastery is not partial; iv) Reflection: involves things that are found outside the classroom; v) Sustainable: is an integral part of the teaching and learning process; vi) Valid: accesses the goals to be achieved by the curriculum; vii) Engages students; and viii) Interprets evaluation results.

\section{CONCLUSION}

The loading factor value ranges from 0.5571-0.9463 and AVE $>0.5$ except for the objective construct because $\mathrm{LF}>0.5$ and $\mathrm{AVE}>0.5$. Thus, it can be concluded that the instrument has a convergent validity guarantee. The square root value of AVE is higher than the correlation value between constructs, so the instrument has a guarantee of discriminant validity. Reliability composite values range from 0.8394-0.9397 and the Cronbach alpha values range from 0.7692-0.9286, because of CR>0.8 and Cronbach alpha>0.7, the instrument item has reliability assurance. The evaluation instrument can be used to measure curriculum evaluation in Al-Irsyad schools in Indonesia.

Development of curriculum design evaluation instruments in strengthening Al-Irsyad ... (Joko Subando) 
This study proofed the form of instruments that can be used to evaluate the process of strengthening Al-Irsyad ideology. The results of the evaluation provide recommendations related to the quality aspects of teacher and student interactions in the process of strengthening ideologies that are already strong or weak. The instrument that was successfully developed was of course only for the strengthening of Al-Irsyad ideology, not Muhammadiyah, Nahdlatul Ulama (NU), or other religious organizations. However, this research can be used as a basis for further research to develop instruments for strengthening other religious ideologies.

\section{REFERENCES}

[1] M. Apple and M. W. Apple, Ideology and curriculum. Routledge, 2018.

[2] S. Saparudin, Religious ideology in education: Dissemination and contestation at madrasa and Islamic schools in Lombok, (in Indonesia). Jakarta: Onglam Books, 2017.

[3] T. Suharto, "Transnational Islamic education in Indonesia: an ideological perspective," Contemporary Islam, vol. 12, pp. 101-122, 2018, doi: 10.1007/s11562-017-0409-3.

[4] T. Suharto, "Kontestasi Ideologi Antara Pendidikan Nasional Dan Pendidikan Islam Transnasional di Indonesia," in The Proceeding of The 16th Annual International Conference on Islamic Studies (AICIS), The Dynamics of Islamic Institutions, 2016. [Online]. Available: http://repository.ikhac.ac.id/id/eprint/582.

[5] L. Althusser, On ideology. Verso Books, 2020.

[6] C. Tan, Reform in Islamic Education International Perspectives. London: Bloomsbury Academic, 2014.

[7] Y. Shan, P. Yang, and X. Xu, "Reform and Evaluation of Curriculum Design in Baccalaureate Nursing Program," Journal of Nursing Science, vol. 18, 2005.

[8] A. N. Huda, "Evaluation of Al Islam Kemuhammadiyahan Curriculum and Integrative-Holistic-Based Arabic at SMA Muhammadiyah 1 Muntilan," (in Indonesia), Jurnal Tarbiyatuna, vol. 9, no. 2, pp. 134-150, 2018, doi: 10.31603/tarbiyatuna.v9i2.2414.

[9] S. Shodiq, "Transmission of the Ideology of Ahlussunnah Wal Jama'ah: Evaluation Study of Nuclearity Learning at Al-Ma'ruf High School Kudus," (in Indonesia), Nadwa: Jurnal Pendidikan Islam, vol. 9, no. 2, pp. 183-198, 2015, doi: 10.21580/nw.2015.9.2.523.

[10] H. Nashir, Muhammadiyah Renewal Movement, (in Indonesia). Jakarta: Suara Muhammadiyah, 2010.

[11] P. A.-I. Al-Islamiyyah, Mabadi Al-Irsyad and its explanation, (in Indonesia). Jakarta: PP Al-Irsyad Al-Islamiyyah, 2012.

[12] K. Thohiri, “A Paradigm Shift of 'Aswaja An-Nahdliyyah': An Institutional Approach to the Internal Dynamics of Nahdlatul Ulama," Epistemé: Jurnal Pengembangan Ilmu Keislaman, vol. 14, no. 2, pp. 305-326, 2019, doi: 10.21274/epis.2019.14.2.305-326.

[13] N. Mobini-Kesheh, "Islamic Modernism In Colonial Java: The Al-Irshad Movement," in Hadhrami Traders, Scholars and Statesmen in The Indian Ocean, the 1750s-1960s. Leiden, New York, and Köln: Brill, 1997, pp. 231-248.

[14] B. Affandi, "Shaykh Ahmad al-Surkati: His Role In Al-Irshad Movement In Java In The Early Twentieth Century," M.S. thesis, McGill University Libraries, 1976.

[15] M. Miftahuddin and A. Sudrajat, "Identity crisis, contestation, and conflict within The Hadrami Community of AlIrsyad 1990-2007,” Journal of Social Studies (JSS), vol. 13, pp. 53-62, 2017, doi: 10.21831/jss.v13i1.16973.

[16] D. P. Anggy Maulana, "Evaluation On Affective Domain of The Islamic Education With Progress Report in SMP Al Irsyad Al Islammiyyah Purwokerto,” M.S. thesis, IAIN Purwokerto, 2019.

[17] S. Danks, "The ADDIE Model: Designing, Evaluating Instructional Coach Effectiveness," ASQ Primary and Secondary Education Brief, vol. 4, no. 5, pp. 1-6, 2011.

[18] L. R. Aiken, "Three Coefficients for Analyzing the Reliability and Validity of Ratings," Educational and Psychological Measurement, vol. 45, no. 1, pp. 131-142, 1985, doi: 10.1177/0013164485451012.

[19] M. W. Watkins, "Exploratory Factor Analysis: A Guide to Best Practice," Journal of Black Psychology, vol. 45, no. 1, pp. 219-246, 2018, doi: 10.1177/0013164485451012.

[20] S. Ahmad and W. Afthanorhan, "The Importance-Performance Matrix Analysis In Partial Least Square Structural Equation Modeling (PLS-SEM) with smart pls 2.0 M3," International Journal of Mathematics Research, vol. 3, no. 1, pp. 1-14, 2014, doi: 10.18488/journal.24/2014.3.1/24.1.1.14.

[21] A. Rouf Md and M. Akhtaruddin, "Factors Affecting The Voluntary Disclosure: A Study By Using Smart PLSSEM approach," International Journal of Law and Management, vol. 60, no. 6, pp. 1498-1508, 2018, doi: 10.1108/IJLMA-01-2018-0011.

[22] M. Sarstedt and J.-H. Cheah, "Partial Least Squares Structural Equation Modeling Using SmartPLS: A Software Review," Journal of Marketing Analytics, vol. 7, pp. 196-202, 2019, doi: 10.1057/s41270-019-00058-3.

[23] L. L. Chan and N. Idris, "Validity and Reliability Of The Instrument Using Exploratory Factor Analysis and Cronbach's Alpha," International Journal of Academic Research in Business and Social Sciences, vol. 7, no. 10, pp. 400-410, 2017, doi: 10.6007/IJARBSS/v7-i10/3387.

[24] I. Ghozali, Structural Equation Modeling: Alternative Method with Partial Least Square, (in Indonesia). Semarang: Badan Penerbit Universitas Diponegoro, 2014.

[25] N. U. Hadi, N. Abdullah, and I. Sentosa, "An easy approach to exploratory factor analysis: Marketing perspective," Journal of Educational and Social Research, vol. 6, no. 1, pp. 215-223, 2016, doi: 10.5901/jesr.2016.v6n1p215. 
[26] F. F. A. Munir, "Reliability and Validity Analysis on The Relationship Between Learning Space, Student's Satisfaction And Perceived Performance Using SMART-PLS," International Journal of Academic Research in Business and Social Sciences, vol. 8, no. 1, pp. 775-783, 2018.

[27] M. Khoshmaram, K. Zarafshani, A. Alibaygi, and A. Mirakzadeh, "Exploring The Role of Social Capital in Agricultural Entrepreneurial Opportunity Recognition: Application of Smart PLS," International Journal of Agricultural Management and Development, vol. 7, no. 4, pp. 395-406, 2017, doi: 10.22004/ag.econ.292503.

[28] M. Ab Hamid, W. Sami, and M. Sidek, "Discriminant Validity Assessment: Use of Fornell \& Larcker criterion versus HTMT criterion," Journal of Physics: Conference Series, vol. 890, 2017, pp. 1-5, doi: 10.1088/17426596/890/1/012163.

[29] V. Silaparasetti, G. Rao, and F. R. Khan, "Structural Equation Modeling Analysis Using Smart PLS to Assess The Occupational Health and Safety (OHS) Factors on Workers' Behavior," Humanities \& Social Science Reviews, vol. 5, no. 2, pp. 2395-7654, 2017, doi: 10.18510/hssr.2017.524.

[30] M. Gultom, S. Sumarno, and S. Madya, "Reflective Evaluation Model of English Education Curriculum in Developing National Character," (in Indonesia), Jurnal Penelitian dan Evaluasi Pendidikan, vol. 18, no. 1, pp. 72-88, 2014, doi: 10.21831/pep.v18i1.2125.

[31] W. Tyler, Basic Principles of Curriculum Development and Instruction. Chicago: University of Chicago Press, 1949.

[32] L. Brady and K. Kennedy, Curriculum construction. Pearson Higher Education AU, 2013.

[33] W. Sanjaya, Curriculum and Learning, (in Indonesia). Kencana, 2008.

[34] A. C. Ornstein and F. P. Hunkins, Curriculum: Foundations, Principles, and Issues. Saddle River, NJ: Pearson, 2013.

[35] M. Ansyar, Curriculum: Itself, Foundation, Design and Development, (in Indonesia). Prenada Media, 2015.

[36] H. Taba, Curriculum Development: Theory and Practice. New York: Harcourt Brace Jovanovich. Inc, 1962.

[37] R. Harris, B. Hobart, and D. Lundberg, Competency-based education and training: Between a rock and a whirlpool. Macmillan Education AU, 1995. 